\title{
The future landscape of New Zealand agriculture
}

\author{
B.S.THORROLD \\ DairyNZ, Private Bag 3221, Hamilton \\ Bruce.Thorrold@dairynz.co.nz
}

\begin{abstract}
Land use change has been a constant theme of New Zealand history. Economics, government policy and farmer choices continue to influence these changes. Current financial drivers are encouraging further growth in the dairy industry through the Canterbury and Southland regions. Changing economic opportunities and government policy around water and nutrient loss will continue to shift the balance of the forces driving land use change. The challenge for business and science is to intensify the competition for land use by lifting the performance of all sectors.
\end{abstract}

\section{Introduction}

Land use is a visual, often emotive and economically critical part of New Zealand life. Land use change is always occurring, often not in a broad pattern across the whole country but regionally specific as new opportunities to use land, sunshine and water attract the attention of farmers and investors. The purpose of this paper is to examine some of the trends and drivers of land use change both in the past and the future.

\section{Two centuries of change}

The pattern of land use and agricultural practises in New Zealand has been subject to change ever since human settlement began. Belich (1996) described how Maori originally adopted a hunting and gardening culture that shifted to gardening, gathering and fishing driven by changing food availability and population growth. Management systems included use of soil amendments, use of fire and the systematic planting and harvesting of native and introduced plants. The arrival of European settlers with a new suite of plants and animals led to further changes in land use and management systems that continue to evolve today.

Given the importance of primary production to the New Zealand economy and the impacts on greenhouse gas emissions, water use and nutrient loss of different land uses and management systems, the way that land use evolves into the future is of considerable importance to New Zealand.

\section{The recent past}

The current patterns of land use can usefully be traced back over the period since the end of the government driven development phase that finished in the mid- 1980s. With government withdrawing from subsidising and promotion of (even belief in) agriculture, farmers and land use have become dominantly driven by market derived economic signals.

Notable trends over this time are captured in Fig. 1 and include:

1. A large increase in the area under dairy farming.

2. An initial increase in the area under plantation forest, but this area has declined from the mid 2000s in part due to conversion of forestry land to pastoral use particularly in the central North Island. Over 200000 ha of forest has been converted over this period.

3. Very large percentage increases (almost 600\%) in the area in viticulture since the mid-1990s. In 2009, this land use occupied 33422 ha, only a small percentage $(<1 \%)$ of total pastoral land and only a fraction of the changes in land use experienced in the pastoral and forestry sectors. Total area in horticulture has been relatively steady over this time (90-120 000 ha) with apples, kiwifruit and avocadoes experiencing growth and decline phases).

4. A large decrease in the area under sheep farming.

All of these changes can be explained by differences in the profitability and capital values of different land uses, influenced by resource limits including slope, soil types and irrigation availability. These changes reinforce the basic land valuation concept that land use will over time move to its best use (Matthews 2010). This is captured conceptually in work by the Motu Research Group (Todd \& Kerr 2009). This depicts the interactions between land use profitability and land slope - with dairying most profitable on flat land, forestry most profitable on steep land and sheep farming intermediate.

Under the right circumstances this can lead to near mono-cultural land use at both small scale (e.g. viticulture in the Wairau Valley) and large scale with corn and soybeans occupying $84 \%$ of the $11 \mathrm{M}$ ha of crop quality land in Iowa (Iowa State University 2010).

\section{Current drivers of change}

As usual, learning from the lessons of the past is a good place to start. However, the drivers of the future 
Figure 1 Changes in land use (ha) from late 1970s to 2009. Due to changes in reporting, all data are not available in every year, representative values for each period are shown. Note the log scale. Source: Statistics NZ.

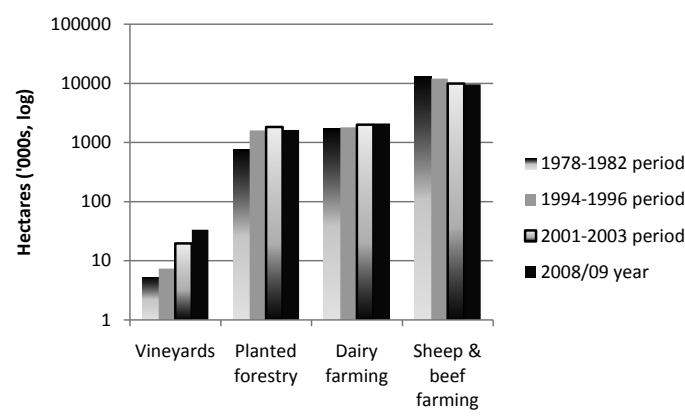

will not be the same in detail as the drivers of the past. There is no sign on the government agenda of Land Development Encouragement Loans, a State Advances Bank, Supplementary Minimum Prices, or the Livestock Taxation policies that drove deer industry expansion. Britain can't join the EEC again, and OSH would never allow live deer capture. However, the interacting roles of economics, government policy and farmer choices still exist overlaid on natural resources of soil type and climate - how might these play out in future?

Competition for land use is currently occurring in the Canterbury and Southland regions where the growth in dairying has been greatest over the last decade. Recent MAF Farm Monitoring reports (MAF 2010) show that the economic pressures are continuing to favour the movement of land away from arable and sheep farming and into dairy. The data in Fig. 2 show average of 5 years of business profitability data, expressed as farm surplus for re-investment as a proportion of equity employed. Farm surplus is calculated after debt servicing and living expenses, so represents the business reality facing current owners. An alternative measure is the pre-debt cash-operating surplus, most usefully expressed as a return on assets employed. Given that the dairy farms in both regions carry significantly higher debt levels than sheep or arable farms, neither measure is perfectbut both give the same result. Dairy farming in both regions over the 5 years of actual and forecast data from $2006 / 2007$ to $2010 / 2011$ shows much higher financial returns.

Change does not happen instantaneously, existing land owners go through a long process of deciding to sell or convert to dairying. Either of these decisions has major implications for farmers, and with rising land values and low debt, existing farmers have not been under huge pressure to change. MAF commentary in the 2010 Farm Monitoring Report identifies that there is on-going debate in these farming businesses about
Figure 2 Comparison between return on equity (\%) for Southland and Canterbury farms averaged over 2006/2007 to 2010/2011. Data from MAF Farm Monitoring Reports (MAF 2010).

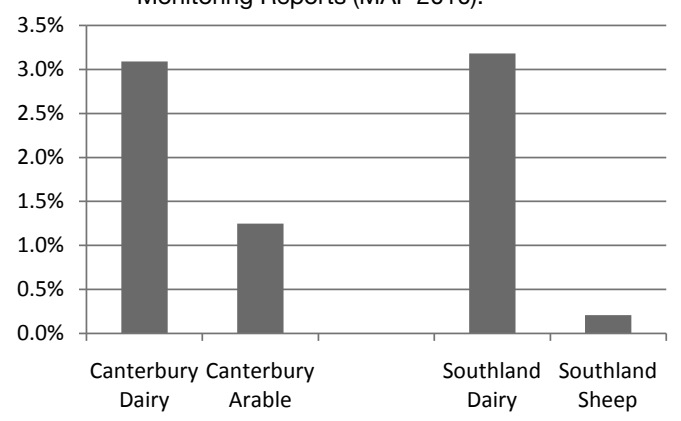

land use change.

So accepting that there is on-going financial pressure to change land use in both Canterbury and Southland, and accepting also the principles that land use will move to its best use and that a monopoly of one land use over others is possible - the question remains, what might shift the balance of the momentum?

\section{Unique advantages - water and bio- security}

New Zealand farmers currently hold two important comparative advantages. These are an abundance of water by world standards (World Bank 2010) and a strong biosecurity system that allows worldwide export of farm produce. Forecast global water shortages may create the opportunity for arable farmers to grow water intensive crops in New Zealand that have priced themselves off the water market overseas. By definition these will not be the highest value crops per unit water consumed - but are those that produce high returns per hectare when water is more freely available. Pyke (2010) explores some of these possibilities for irrigated arable farmers - linking high water availability through the growing season with precision irrigation and biosecurity in a scenario that sees arable farmers increasingly growing higher value seed crops for export.

\section{The return of wool?}

Debates over the organisation of the meat industry have had such a profile that it is easy to overlook the fact that lamb has been a success story for New Zealand farmers. Fig. 3 shows that lamb prices have kept up in real terms with dairy prices over the last 30 years, and sheep farmers have made large productivity gains through improved ewe fertility and lamb growth rates. Fig. 3 also shows that it is the value of wool (down $75 \%$ in real terms) and beef that have been the underperformers. Any increase in wool price goes straight to the profit line for farmers as wool growth is an 
Figure 3 Inflation adjusted farm produce prices from 19082009. From Pangborn \& Woodford (2010).

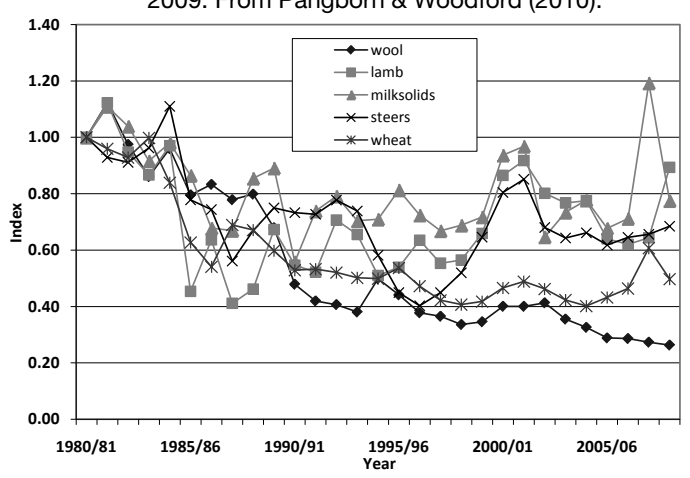

overhead of lamb production. Increased profitability per ewe would encourage sheep farmers to lift pasture production through greater inputs and further increase farm profitability and return on assets.

\section{Constraints on land use impacts}

Carbon costs, nutrient loss limits and visual impacts are three possible constraints that might shift the balance of land use in the Canterbury and Southland regions. Of these, nutrient loss limits seem most likely to impact on land use patterns in the more intensively farmed areas. High intensity land use has the potential to lead to high losses of nutrients (particularly $\mathrm{N}$ and $\mathrm{P}$ ) and sediment to waterways and groundwater. Modern farm practises generally control sediment loss, leaving nutrients as the major concern. Further expansion of the dairy industry will require farmers to adopt more nutrient efficient systems, not simply in terms of nutrient loss or input per kg product, but at the absolute level of nutrient loss per hectare. Increasing profitability of sheep or arable farming would lead to similar pressures as these farmers would also be likely to intensify their operations given improved profitability.

\section{The challenges}

New Zealand is a country whose economy remains highly reliant on primary production. After some decades of government indifference we are now seeing political and industry will to invest in science and support primary industry development. Unlike the diversification focus of the 1980s this cycle includes government focusing on the big dairy and meat industries where scale allows large gains to flow back to the economy.

The challenge for both science and business is to increase the competition between primary sectors for land and other resources. Improving prices, production options and productivity in the arable and sheep sectors, and developing nutrient efficient dairy systems are important steps to lifting the potential of all primary sectors to contribute to farmer and community wealth.

\section{REFERENCES}

Belich, J. 1996. Making peoples A history of the New Zealanders. Penguin Books 497 pp.

Iowa State University 2010. Iowa Soil and Land use. http://extension.agron.iastate.edu/soils/CLU tables. $\underline{\mathrm{html}}$

MAF. 2010. Pastoral monitoring 2010. http://www. maf.govt.nz/mafnet/rural-nz/statistics-and-forecasts/ farm-monitoring/2010/pastoral/index.htm

Matthews, L. 2010. Changing land use in Canterbury. The effect and implications for rural valuations. Primary Industry Management 14: 10-15.

Pangborn, M.; Woodford, K. 2010. The rise and rise of Canterbury dairying. Primary Industry Management 14: 3-8.

Pyke, N. 2010. Overview and future opportunities for the New Zealand arable industry. Primary Industry Management 14: 41-43.

Todd, M.; Kerr, S. 2009. How does changing land cover and land use in New Zealand relate to land use capability and slope? Motu Working Paper 09-17.

World Bank, 2010. World development indicators. http://data.worldbank.org/data-catalog/worlddevelopment-indicators?cid=GPD WDI 
